\title{
Hatching Glands in Herring Embryos
}

\author{
H. Rosenthal ${ }^{1}$ and T. Iwai ${ }^{2}$ \\ 1 Biologische Anstalt Helgoland, Palmaille 9, D-2000 Hamburg 50, Federal Republic of Germany \\ ${ }^{2}$ Department of Fisheries, Kyoto University, Kyoto, Japan
}

\begin{abstract}
This investigation reports on the first appearance of hatching glands during embryonic development of Clupea harengus. It provides information on morphological gland detail and documents the distribution of the glands on the embryo as well as their total number and disappearance after hatching. The first hatching glands occur after the beginning of eye pigmentation. The glands extend in the epidermal layer from the tip of the snout to the pectoral fins along the dorsal surface of the trunk. They are oval in shape, 16 to $20 \mu \mathrm{m}$ long, 10 to $14 \mu \mathrm{m}$ wide, and apparently of holocrine nature. Mature cells are filled with granules. The total number of glands varies between approximately 1500 to 2000 per embryo. Within 3 to $5 \mathrm{~h}$ after hatching all glands had disappeared.
\end{abstract}

\section{INTRODUCTION}

At hatching, the protective envelope of teleost embryos - the egg capsule - must be penetrated by the emerging larvae. The chemical composition of the egg capsule was studied in salmonids by Hagenmaier (1973) and in cyprinids by Arndt (1960). Mucopolysaccharides and proteins seem to be its major components. The inner layer of the egg capsule is digested by a hatching enzyme, thereby substantially reducing capsule strength (Alderdice et al., 1979). Hatching through the outer layer is solely a physical process. The hatching enzyme is secreted by epidermal glands which differentiate during the latter half of the incubation time. In teleost embryos the chemical nature of the hatching enzyme and its proteolytic properties was investigated by Hayes (1942), Ishida (1944a, b), Bell et al. (1969), Hagenmaier (1974a, b, 1975), and Yamagami $(1970,1973,1975)$.

Development and morphological characteristics of the glands were described for Oryzias latipes by Yamamoto (1963) and for Plecoglossus altivilis by Iwai (1962). A first brief description of hatching glands in herring embryos has been given by Kryzhanovskii (1956). Fujita and Kokubo (1927) noted the granules on the head of Pacific herring embryos without recognizing and describing their possible function. For the herring Clupea harengus the present investigation reports on the first appearance of hatching glands during embryonic development, provides details on gland morphology, and documents gland distribution

(c) by Inter-Research on the embryo; it further presents information on total number and disappearance of the glands after hatching.

\section{MATERIAL AND METHODS}

Baltic spring spawners of Clupea harengus were collected by fishermen at the fishing harbor of Travemünde. Immediately after landing (about $1 \mathrm{~h}$ after catching by gillnet) they were transported to the laboratory in cooling boxes at $6.0^{\circ} \mathrm{C}$. Eggs were fertilized about $4 \mathrm{~h}$ after catching the parental fish. Fertilization procedures and incubation techniques have been described elsewhere (Rosenthal, 1968; Alderdice and Velsen, 1978; Alderdice et al,, 1979). Eggs were incubated at about $10{ }^{\circ} \mathrm{C}$ and a salinity of $20 \% \mathrm{~S}$. The water in the incubation jars $(300 \mathrm{ml}$ volume) was renewed every other day until the beginning of hatching.

Hatching gland development was followed by microscopic observations. The total number of glands was estimated by counting those covering the otic capsule or lying on a cross-section between the eyes. For histological studies, embryos of advanced developmental stages were dechorionated under the microscope and fixed in a $10 \%$ formalin-calcium solution. Several series of larvae, at various stages afier hatching, were fixed in the same solutions. After embedding in paraffin, embryos and larvae were serially sectioned $(7 \mu \mathrm{m})$. The sections were then stained with Mayer's haemalaun and eosin or with safranin and light green. 


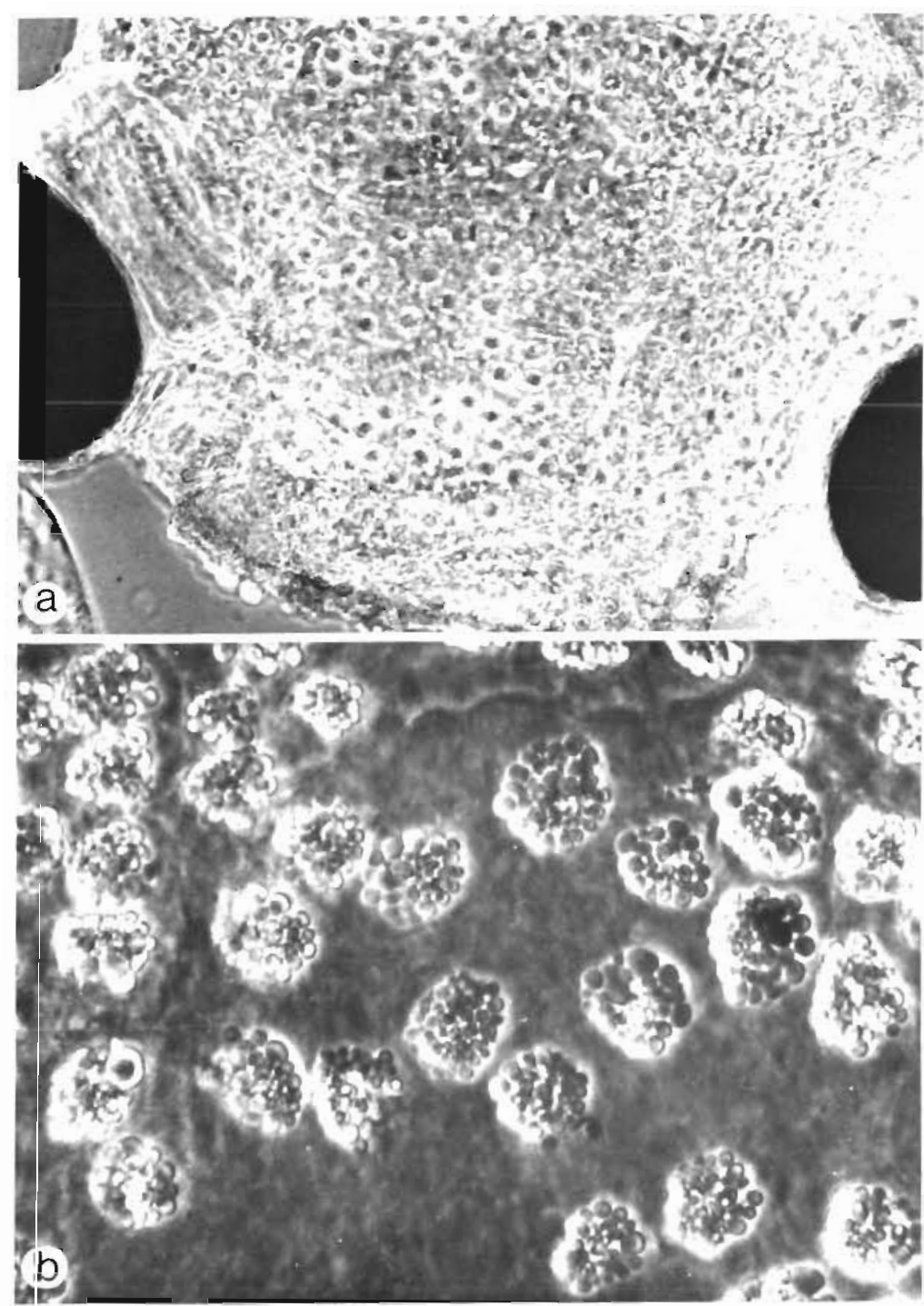

Fig. 1. Clupea harengus. Hatching glands in embryos and their distribution on the front part of the head (a). The unicellular glands are filled with granules (b)

\section{RESULTS}

The occurrence of a few hatching glands can be observed on the front part of the head region shortly after the beginning of eye pigmentation (e. g. 3-4 days prior to hatching). They increase rapidly in number sometimes occurring in irregular clusters (Fig. 1a).

The hatching glands are oval in shape, $16-30 \mu \mathrm{m}$ long and $10-14 \mu \mathrm{m}$ wide. They are embedded in a single layer in the epidermis. As in other teleost embryos, they are unicellular in structure, and mature cells are filled with many secretory granules measuring about $2-3 \mu \mathrm{m}$ in diameter (Fig. $1 \mathrm{~b}, 2 \mathrm{c}$ and $2 \mathrm{~g}$ ). The granules exhibit a strong stainıng reaction to eosin and light green. The nucleus is located in the basal or lateral border of the cell (Fig. 2c and $2 \mathrm{~g}$ ). The hatching glands seem to be holocrine in nature and most of them discharge immediately before hatching.

In embryos of about 5.8 to $6.0 \mathrm{~mm}$ total length $(24 \mathrm{~h}$ prior to hatching) hatching glands are distributed in the epidermal layer from the tip of the snout to the dorsal surface of the anterior portion of the trunk at the level of the pectoral fin. In the head region the glands are densely packed along the dorso-lateral surface, also occurring on eyes and otic capsules (Fig. 2a-d). However, the distribution area of the glands narrows posteriorly, and the glands are restricted towards the dorsal surface at the level of the pectoral fin or between the 2 nd and 3rd somites (Fig. 2f). No hatching glands were observed on the yolk surface, but a few exist on the lower jaw

Table 1 lists the number of hatching glands observed 

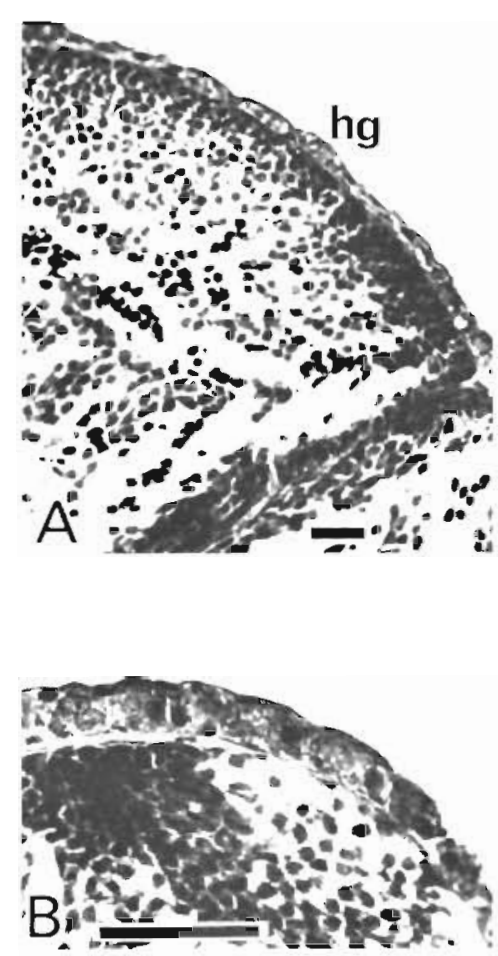
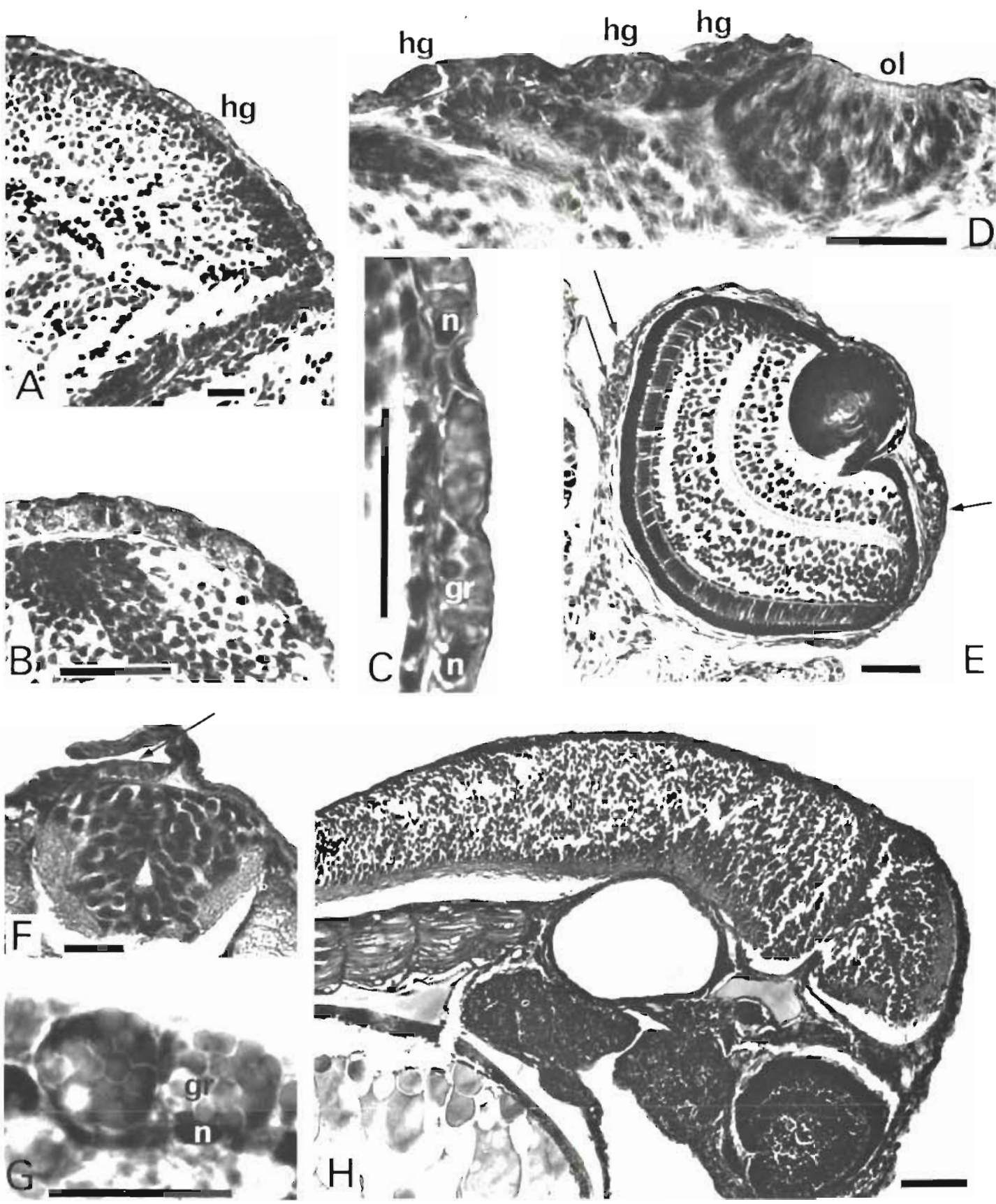

Fig. 2. Clupea harengus. Hatching glands in embryos. Longitudinal sections through (A) parietal, (B) frontal and (C) occipital region of the head showing densely arranged rows of glands in the epidermal layer. (D) Horizontal section through the olfactory pit with a marginal row of glands. (E) Transverse section through the eye exhibiting glands in the epidermal layer (arrows). (F) Transverse section through the region of the second somite showing hatching glands (arrow) near the base of the dorsal fin fold. (G) Hatching gland filled with granules. (H) Longitudinal section through the head of a herring larva $12 \mathrm{~h}$ after hatching (no hatching glands present in the epidermal layer) $\mathrm{gr}=$ granule $\mathrm{hg}=$ hatching gland; $\mathrm{n}=$ nucleus; ol $=$ olfactory pit. Calibration bars: $30 \mu \mathrm{m}$ for $\mathrm{A}-\mathrm{F}, 20 \mu \mathrm{m}$ for $\mathrm{G}$, and $60 \mu \mathrm{m}$ for $\mathrm{H}$

which cover the otic capsule, and the calculated number per unit area in relation to incubation time. Although the number of holocrine glands covering the otic capsule increases with time, the total average number per unit area remains almost constant from the beginning of hatching onward (i. e. $265 \mathrm{~h}$ after fertilization); this is mainly due to the continuous growth of the otic capsule. 
Table 1. Clupea harengus. Hatching glands in embryos. Number of glands per unit area prior to and during hatching. $h$ incubation time in hours; $n$ number of observations; (a) average number of glands covering the otic capsule; (b) calculated number per unit area $\left(\mathrm{mm}^{2}\right) ; \bar{x}$ mean, SD standard deviation

\begin{tabular}{|c|c|c|c|c|c|c|}
\hline \multirow{2}{*}{$\mathrm{h}$} & \multirow{2}{*}{$\mathrm{n}$} & \multicolumn{2}{|c|}{$\begin{array}{c}\text { Size of otic capsule } \\
\left(\mathrm{mm}^{2}\right)\end{array}$} & \multicolumn{3}{|c|}{ Number of hatching glands } \\
\hline & & $\overline{\mathrm{x}}$ & $\mathrm{SD}$ & & $\bar{x}$ & $\mathrm{SD}$ \\
\hline 168 & 10 & 0.016 & 0.002 & 13.2 & 837 & 180 \\
\hline 192 & 13 & 0.018 & 0.004 & 22.7 & 1290 & 165 \\
\hline 240 & 4 & 0.047 & 0.002 & 63.3 & 1346 & 127 \\
\hline 264 & 11 & 0.050 & 0.005 & 66.7 & 1347 & 170 \\
\hline 295 & 8 & 0.058 & 0.005 & 73.6 & 1294 & 170 \\
\hline
\end{tabular}

The total number of hatching glands per embryo can be estimated only in very approximate terms. Assuming a more or less uniform distribution and a total area covered by hatching glands of about 1.2 to $1.5 \mathrm{~mm}^{2}$, the total number of glands may vary between approximately 1500 to 2000 per embryo. These estimates are in good agreement with counts in other fish species (Plecoglossus sp. $=1600$, Iwai, 1962; Hypomesus sp. $=1100$, Yanai et al., 1956).

The number of glands seems to decrease in embryos which are still in their eggshell after 50\% hatching time. After hatching the glands disappear rapidly (Fig. 2h). In newly-hatched larvae a few glands can still be seen along the dorsal surface between the tip of the snout and the $3 \mathrm{rd}$ somite. In one case 30 glands were found along the longitudinal axis, but they disappeared rapidly. At hatching glands have neither been observed on eyes nor on otic capsules. Within 3 to $5 \mathrm{~h}$ after hatching all glands had disappeared.

\section{DISCUSSION}

As in other teleosts the hatching glands of Clupea harengus are ectodermal in origin. Their mother cells occur first in lateral patches between otic capsule and eye-anlage. Our findings in herring embryos are in accordance with observations by Yanai et al. (1956) in embryos of Carassius auratus, Salanx microdon and Hypomesus olidus. In Plecoglossus altivelis enlarged cells accumulate first within the epidermis near the lateral side of the occipital region of the embryo (Iwai, 1962).

In Clupea harengus the first hatching glands are formed at an ontogenetically early stage. Similarly, the first hatching glands of trout embryos occur at the stage of early eye pigmentation (Hagenmaier, $1974 a, b)$.

The size of hatching glands varies considerably in fishes investigated so far. In Plecoglossus embryos each gland comprises one cell measuring $7-8 \mu \mathrm{m}$ in diameter (Iwai, 1962). In Hypomesus embryos, hatching glands measure $10 \mu \mathrm{m}$ in length, and $5 \mu \mathrm{m}$ in width, with the nucleus situated near the basal end of the cell (Yanai et al., 1956). In herring embryos the glands are at least twice as large. Ishida (1944a) reports that the average diameter of gland cells reaches about $18 \mu \mathrm{m}$ in Oryzias latipes. Similar diameters $(20 \mu \mathrm{m})$ have been found in Salmo gairdneri embryos (Hagenmaier, 1974b).

The distribution of hatching glands at the time of hatching differs in the species investigated. In Plecoglossus altivilis the glands extend along both lateral sides of the embryo from the shoulder to the anus (Iwai, 1962). In embryos of Oryzias latipes, they develop within the oral cavity (Ishida 1944a, b).

In the cottid fish Orthonopias triacis patches of hatching cells are found on the head of the embryo (Bolin, 1941). In the goldfish Carassius auratus they occur on the lateral surface of the trunk and on the yolk sac (Ouji, 1955) whereas in Salangichthis they appear along the dorsal surface of the embryo (Yanai, 1953). In Pacific salmon embryos (Oncorhynchus keta) they occur on both the body surface and the oral cavity (Disler, 1957). Hagenmaier (1974a, b) reported finding in embryos of rainbow trout additional glands on the front part of the yolk sac. In Baltic herring embryos, no hatching glands have been found on the yolk epithelium.

The mechanism triggering the release of granules from hatching glands remains to be explored. Ishida (1944a) assumes that the membrane surrounding the granules may be ruptured mechanically due to increasing embryo activity. Therefore, changes in incubation time of fish embryos due to changes in environmental stress (natural or pollutional) may be caused by altered embryo activity as has been shown by Westernhagen et al. (1979). Quantitative observations on changes of embryo activity prior to hatching may, therefore, be considered as an important sublethal response to environmental perturbation (Westernhagen et al., 1975). 


\section{LITERATURE CITED}

Alderdice, D. F. and Velsen, F. P. J. (1978). Effects of shortterm storage of gametes on fertilization of Pacific herring eggs. Helgoländer wiss. Meeresunters., 31, 485-498.

Alderdice, D. F., Rosenthal, H. and Velsen, F. P. J. (1979). Influence of salinity and cadmium on capsule strength in Pacific herring eggs. Helgoländer wiss. Meeresunters., 32, 149-162.

Arndt, E. A. (1960). Untersuchungen über die Eihüllen von Cypriniden. Z. Zellforsch. Inikrosk. Anat., 52, 315-327.

Bell, G. R., Hoskins, G. E. and Bagshaw, J. W. (1969). On the structure and enzymatic degradation of the external membrane of the salmon egg. Can. J. Zool, 47, 146-148.

Bolin, R. L. (1941). Embryonic and early larval stages of the cottid fish Orthonopias triacis Starks and Mann. Stanford ichthyol. Bull., 2, 73-82

Disler, N. N. (1957). Development of autumn salmon Oncorhynchus keta (Waldb.) in the Amur river. (Russ.) Trudy Inst. Animal Morph., 20, 3-70.

Fujita, T. and Kokubo, S. (1927). Studies on herring. (Jap.; Engl. summary.) Bull. Sch. Fish., Hokkaido imp. Univ., 1, $1-141$.

Hagenmaier, H. E. (1973). The hatching process in fish embryos. III. The structure, polysaccharide and protein cytochemistry of the chorion of the trout egg Salmo gairdneri. Acta histochem., 47, 61-69.

Hagenmaier, H. E. (1974a). The hatching process in fish embryos. IV. The enzymological properties of a highly purified enzyme (chorionase) from the hatching fluid of the rainbow trout, Salmo gairdneri Rich. Comp. Biochem. Physiol., 49 B, 313-324.

Hagenmaier, H. E. (1974b). Zum Schlüpfprozeß bei Fischen. VI. Entwicklung, Struktur und Funktion der Schlüpferdrüsenzellen bei der Regenbogenforelle, Salmo gairdneri Rich. Z. Morph. Tiere, 79, 233-244.

Hagenmaier, H. E. (1975). Zur Isolierung und Charakterisierung eines Schlüpfenzyms bei der Regenbogenforelle, Salmo gairdneri Rich. Verh. dt. zool. Ges., 1974, 163-166.

Hayes, F. R. (1942). The hatching mechanism of salmon eggs. J. exp. Zool., 89, 357-373.

Ishida, J. (1944a). Hatching enzyme in the fresh-water fish, Oryzias latipes. Annotnes zool. jap., 22, 137-154.

Ishida, J. (1944b). Further studies on the hatching enzyme of the freshwater fish, Oryzias latipes. Annotnes zool. jap. $22,155-164$

Iwai, T. (1962). Studies on the Plecoglossus altivelis problems: Embryology and histophysiology of digestive and osmoregulatory organs. Bull. Misaki mar. biol. Inst., Kyoto Univ., 2, 1-101.

Kryzhanovskii, S. G. (1956). Data on development of clupeid fishes. (Russ.) Trudy Inst. Animal Morph., Acad. Sci. USSR, 17, 1-255.

Ouji, M. (1955). Morphology and development of the hatching glands of the teleost, Cyprinus auratus. (Jap.; Engl. summary.) Zool. Mag., Tokyo, 64, 277-279.

Rosenthal, H. (1968). Schwimmverhaiten und Schwimmgeschwindigkeit bei den Larven des Herings Clupea harengus. Helgoländer wiss. Meeresunters., 18, 453-486.

Westernhagen, H. von, Dethlefsen, V. and Rosenthal, $\mathrm{H}$. (1975). Combined effects of cadmium and salinity on development and survival of garpike eggs. Helgoländer wiss. Meeresunters., 27, 268-282.

Westernhagen, H. von, Dethlefsen, V. and Rosenthal, $H$. (1979). Combined effects of cadmium, copper and lead on developing herring eggs and larvae. Helgoländer wiss. Meeresunters., 32, 257-278.

Yamagami, K. (1970). A method for rapid and quantitative determination of the hatching enzyme (chorionase) activity of the medaka, Oryzias latipes. Annotnes zool. jap., $43,1-9$.

Yamagami, K. (1973). Some enzymological properties of a hatching enzyme (Chorionase) isolated from the freshwater teleost, Oryzias latipes. Comp. Biochem. Physiol., $46 \mathrm{~B}, 603-616$.

Yamagami, K. (1975). Relationship between two kinds of hatching enzymes in the hatching liquid of the medaka, Oryzias latipes. J. exp. Zool., 192, 127-132.

Yamamoto, M. (1963). Electron microscopy of fish development. I. Fine structure of the hatching glands of embryos of the teleost, Oryzias latipes. J. Fa. Sci. Tokyo Univ., Sec. IV, 10, 115-121.

Yanai, T. (1953). Hatching glands of the bony fish, Salanx microdon. (Jap.; Engl. summary.) Zool. Mag., Tokyo, 62, $19-22$.

Yanai, T., Ouji, M. and Iga, T. (1956). Development of the hatching glands in the teleost, Hypomesus olidus (Pallas). Annotnes zool. jap., 29 (4), 202-206. 